\title{
NON-SPECIFIC URETHRITIS TREATED WITH PYRROLIDINOMETHYL TETRACYCLINE NITRATE*
}

\author{
BY \\ C. B. S. SCHOFIELD AND G. MASTERTON \\ Department of Venereology, c/o Ruchill Hospital, Glasgow
}

The oral tetracyclines, especially oxytetracycline, are established in the treatment of non-specific urethritis, but oral therapy has the disadvantage that drugs have to be taken at stated times in set doses. Patients attending Venereal Diseases clinics are especially unreliable in this respect since they tend to stop taking the tablets when symptoms subside.

Tetracyclines for injection, in the form of tetracycline hydrochloride and tetracycline phosphate complex, have long been available, but they produce so much local tissue reaction and pain that they are unacceptable for general use. $\mathrm{N}$ (pyrrolidinomethyl) tetracycline ( $\mathrm{P} \mathbf{M}$ ) was produced by the aminomethylation of tetracycline by Siedel, Söder, and Lindner (1958) and this compound was found by Dimmling, Hüner, Lutzeyer, and Simon (1958) to cause less pain after injection than the parenteral forms of tetracycline hydrochloride and tetracycline phosphate complex.

"Tetrex P M T", the product under investigation for treatment reactions and therapeutic effects, contains pyrrolidinomethyl tetracycline nitrate equivalent to pyrrolidinomethyl tetracycline 350 mg., lignocaine hydrochloride $40 \mathrm{mg}$., ascorbic acid $575 \mathrm{mg}$., and magnesium gluconate $253 \mathrm{mg}$.; it was reconstituted with $2 \mathrm{ml}$. water for injection.

\section{Methods}

The initial diagnosis of non-specific urethritis was based on appearances in Gram-stained urethral smears; but additionally swabs of urethral secretion were sent in Stuart's transport medium to two laboratories where they were cultured for $N$. gonorrhoeae and Trichomonas vaginalis. Patients diagnosed as suffering from nonspecific urethritis were given one injection $(2 \mathrm{ml}$.) of the tetracycline preparation immediately and a second 24 hours later. They were requested to return for surveillance on Day 4 or 5, at which time the prostate was examined; if material was obtainable, smears and cultures were taken, as on Days $8,15,22$, and 29 , and

$\star$ Received for publication May 8, 1968. fortnightly thereafter for up to 3 months after treatment. Patients expecting to leave the locality within 2 weeks were excluded from the investigation. A total of 101 male patients was included in the study.

\section{Results}

Treatment Reactions $23(24.2$ per cent.) of the 95 patients returning after the first injection complained of treatment reactions (Table I). Pain was the most notable reaction; this varied in intensity from moderate to severe and was in some cases so severe as to make the patient refuse a second injection. No patient who received the second injection made any complaint of pain.

TABLE I

REACTIONS TO FIRST INJECTION

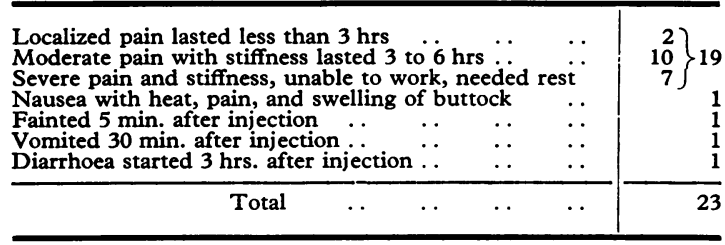

Rejects from the Trial Five patients were later rejected when the results of the urethral cultures were known. Four were found to be suffering from gonorrhoea and one had a Trichomonas vaginalis infection. Twelve other patients received only one injection, for various reasons: six defaulted after their first attendance and did not return within 3 months; three did not return in 24 hours, but did so later, two having relapsed after taking alcohol; two refused the second injection because of the pain, but neither relapsed. One patient developed a haematoma in the buttock and was not given a second injection; his urethritis relapsed on day 8 following re-exposure and ingestinn ci alcohol. 
Results of Planned Treatment 84 patients received two injections as planned. 56 were single, 25 married, two were separated, and one was a widower. Their average age was 30 years. 41 gave no previous history of urethritis, but the other 43 had suffered 59 previous episodes of non-specific urethritis between them. The contacts of sixty patients were unknown casual acquaintances, seventeen were friends, and seven were wives.

The follow-up after treatment is set out in Table II. Twenty patients completed the 3 months' surveillance satisfactorily; forty had defaulted before this time but when clinically satisfactory.

In five cases the urethritis never cleared. Three of these patients had prostatitis, and two uncomplicated urethritis, one of whom had continued to drink alcohol very heavily. There were 24 cases of recurrence of urethritis all within 2 months of treatment. Re-infection after further sexual intercourse accounted for 11 , including the two cases of gonorrhoea; four of these had taken alcohol. There were thirteen cases of relapse; ten of these patients admitted taking alcohol.

TABLE II

RESULTS OF TREATMENT WITH TETREX P M T

\begin{tabular}{|c|c|c|c|c|}
\hline \multirow{3}{*}{$\begin{array}{l}\text { Length of } \\
\text { Follow-up } \\
\text { (days) }\end{array}$} & \multirow{3}{*}{$\begin{array}{l}\text { Number } \\
\text { Followed }\end{array}$} & \multicolumn{3}{|c|}{ Results at Last Attendance } \\
\hline & & \multirow{2}{*}{ Satisfactory } & \multicolumn{2}{|c|}{ Recurrence } \\
\hline & & & Re-exposure & Relapse \\
\hline $1-7$ & 84 & 8 & 2 & 7 \\
\hline $8-14$ & 67 & 1 & 1 & 2 \\
\hline $15-21$ & 63 & $\mathbf{0}$ & 2 & 2 \\
\hline $22-28$ & 59 & 4 & $\mathbf{0}$ & 1 \\
\hline $29-60$ & 54 & 16 & $6^{*}$ & 1 \\
\hline $61-90$ & 31 & 11 & 0 & $\mathbf{0}$ \\
\hline $91+$ & 20 & 20 & 0 & $\mathbf{0}$ \\
\hline Total & 84 & 60 & 11 & 13 \\
\hline
\end{tabular}

*'Two showed $N$. gonorrhoea on culture

If treatment failure is taken as failure of urethritis to clear or as recurrence within 14 days of the initial clearing of the urethritis without re-exposure to infection, then there were nine such failures in this series; these are set out according to the site of the inflammation (urethritis or prostatitis) in Table III. Of the 78 cases of urethritis there were two failures and seven recurrences, four following further sexual exposure. Of the six cases of prostatitis, three failed to respond to treatment and one recurred; none of these was associated with further exposure to risk of infection.
TABLE III

RECURRENCES WITHIN 14 DAYS OF URETHRITIS CLEARING

\begin{tabular}{c|c|c|c|c}
\hline $\begin{array}{c}\text { Site of } \\
\text { Inflammation }\end{array}$ & Number & $\begin{array}{c}\text { Re- } \\
\text { currences }\end{array}$ & $\begin{array}{c}\text { Re- } \\
\text { exposures }\end{array}$ & Relapses \\
\hline Urethra & 9 & 4 & 5 \\
\hline Prostate & 6 & 4 & 0 & 4 \\
\hline Total & 84 & 13 & 4 & 9 \\
\hline
\end{tabular}

\section{Discussion}

Reactions to treatment were noted by $23(24 \cdot 2$ per cent.) of the 95 patients who returned after their first injection; nineteen ( 20 per cent.) complained of pain which varied from moderate to severe, and this is a problem which has to be overcome as it was a cause of default, although it was not so serious as that experienced with earlier intramuscular tetracyclines. No patient complained of any complications after the second injection, not even those who had complained of severe pain after the first. There was no evidence that the drug itself was concerned in the other reactions, which could indeed have followed any injection.

With regard to the four patients rejected from the investigation because of the later culture findings of gonorrhoea, one had a prostatitis and the organisms reappeared on Day 7 ; three patients had uncomplicated gonococcal urethritis, of whom two were cured by their two injections of Tetrex P M T while one relapsed on Day 4 and was cured with penicillin.

Twelve of the patients with non-specific urethritis received one injection only. Of these, six returned for follow-up; the urethritis cleared in three and they completed their surveillance satisfactorily, and the other three relapsed. All these had taken alcohol and one of them admitted re-exposure to risk of infection.

It is difficult to assess the role of defaulters. In addition to the six patients who defaulted after one injection, a further nine defaulted within 21 days of receiving their two injections. When last seen all were clinically satisfactory. There has been no history of their further attendance at any of the local clinics. The possibility is that most were cured, though this cannot be assumed.

All the recurrences developed within 2 months of treatment. Eleven patients admitted further exposure to risk of infection and ten others admitted taking alcohol, which is clear evidence of their indifference to repeated warnings to avoid both. All the recurrences which appeared more than one month after the initial clearing of the urethritis followed further sexual intercourse. 
Of the 78 patients with uncomplicated nonspecific urethritis, only five ( 6.4 per cent.) failed to respond or relapsed within 2 weeks of initial recovery. One had a further relapse one month later and another had two further relapses after 1 month and 3 months. Using comparable criteria but without mentioning default, Morrison (1967) observed relapses of non-specific urethritis in 28 (10.4 per cent.) of 269 patients treated with various drugs. Over a 5-year period during which six schedules of treatment were used, Morton and Read (1957) treated 428 cases of non-specific urethritis, giving altogether 586 courses of the various treatments; if there was no response to one treatment then another was immediately ordered. Of the 428 cases, 28 ( 6.5 per cent.) failed to respond to any treatment. In addition, there were fifty recurrences between 10 days and 4 years 8 months (average 8 months), 22 after fresh exposure, so that there were also 28 (6.5 per cent.) relapses. The lowest failure rate for individual drugs was 15 per cent. after a course of $250 \mathrm{mg}$. oral terramycin 6 hrly. for 4 days. Our results compare favourably with these, as only 6.4 per cent. of our patients with non-specific urethritis failed to respond or relapsed within 2 weeks of initial recovery.

Of the patients with non-specific prostatitis, four out of six relapsed, all by Day 8, two of them after taking alcohol; one patient had two further relapses after treatment with oral tetracyclines. It would therefore appear that Tetrex P M T in the dosage used was ineffective in the treatment of nonspecific prostatitis.

\section{Summary}

In a trial of pyrrolidinomethyl tetracycline nitrate (Tetrex P M T), 101 male patients diagnosed by microscopy as suffering from non-specific urethritis were started on a course of two injections each of $350 \mathrm{mg}$. at an interval of 24 hours. Five patients were rejected from the investigation when $N$. gonorrhoeae or Trichomonas vaginalis was cultured. Six patients did not return after the first injection, and 23 (24.2 per cent.) of the 95 patients who did reported treatment reactions; nineteen of these complained of severe pain at the injection site.

Three of the six patients receiving one injection relapsed. 24 of the 84 who received both injections failed to respond or had a recurrence of nonspecific urethritis, all within 2 months of treatment. Eleven, including two who acquired gonorrhoea, admitted to re-exposure to risk of infection, and a further ten to taking alcohol.

If treatment failure is considered as failure to respond or recurrence without re-exposure within 2 weeks of the urethritis clearing initially, then only five ( 6.4 per cent.) of 78 patients with uncomplicated non-specific urethritis relapsed. This is a more favourable result than those reported after oral tetracycline treatment.

Four of the six patients with non-specific prostatitis relapsed and it would appear that an increased dosage is indicated in such cases.

We wish to thank Bristol Laboratories Limited for the supply of "Tetrex-P M T" for use in this investigation.

\section{REFERENCES}

DIMMLING, T., HÜNER, H., LUTZEYER, W., and SimoN, G. (1958). Münch. med. Wschr., 100, 676. Morrison, A. I. (1967). Brit. F. vener. Dis., 43, 170.

Morton, R. S., and ReAD, L. (1957). Ibid., 33, 223.

SIEDEL, W., SöDER, A , and LINDNER, F. (1958). Münch. med. W schr., 100, 661 .

L'urétrite non-spécifique traitée par le nitrate de tétracycline pyrrolidinométhyle (Tetrex PM T)

\section{RÉSUMÉ}

Dans un essai de traitement par le nitrate de tétracycline pyrrolidinométhyle 101 hommes diagnostiqués au microscope comme étant atteints d'urétrite nonspécifique avaient commencé une série de traitement de 2 injections de $350 \mathrm{mg}$. à un intervalle de 24 heures. 5 malades ont été retirés de l'essai quand le $N$. gonorrhoeae ou le Trichomonas vaginalis était cultivé. Six malades n'étaient pas revenus après la première injection et 23 (24,2 pour cent) des 95 malades qui étaient revenus avaient rapporté avoir eu des réactions au traitement; 19 d'entre eux s'étaient plaints de douleur aiguë autour de l'injection.

Trois des six malades recevant une injection avaient rechuté. 24 des 84 qui avaient reçu les deux injections n'avaient pas répondu au traitement ou avaient eu une rechute de l'urétrite non-spécifique, tous pendant les deux mois qui avaient suivi le traitement. Onze malades y compris deux qui avaient contracté la blennorragie avaient admis qu'ils s'étaient exposés de nouveau au risque d'une infection, et dix autres avaient admis qu'ils avaient pris de l'alcool.

Si l'échec au traitement est considéré comme un échec de répondre ou comme une rechute sans réexposition pendant deux semaines après que l'urétrite avait disparu alore seulement 5 (6,4 pour cent) des 78 malades atteints d'urétrite non-spécifique sans complications avaient rechuté. Ce résultat est plus favorable que celui rapporté après le traitement par la tétracycline par voie buccale:

Quatre des six malades atteints de prostatite nonspécifique avaient rechuté et il semblerait qu'une posologie plus forte serait indiquée dans ces cas. 